\title{
Current perspectives on the immunopathogenesis of systemic sclerosis
}

\author{
This article was published in the following Dove Press journal: \\ ImmunoTargets and Therapy \\ II April 2016 \\ Number of times this article has been viewed
}

\section{Patrizia Fuschiotti \\ Division of Rheumatology and Clinical Immunology, Department of Medicine, University of Pittsburgh School of Medicine, Pittsburgh, PA, USA}

Correspondence: Patrizia Fuschiotti Division of Rheumatology and Clinical Immunology, Department of Medicine, University of Pittsburgh School of Medicine, S709 BST, 200 Lothrop Street. Pittsburgh, PA I526I, USA

Tel + I 4126489385

Fax +I 4I23838864

Email paf23@pitt.edu
Abstract: Systemic sclerosis (SSc or scleroderma) is a progressive and highly debilitating autoimmune disorder characterized by inflammation, vasculopathy, and extensive fibrosis. SSc is highly heterogeneous in its clinical presentation, extent and severity of skin and internal organ involvement, and clinical course and has the highest fatality rate among connective tissue diseases. While clinical outcomes have improved in recent years, no current therapy is able to reverse or slow the natural progression of SSc, a reflection of its complex pathogenesis. Although activation of the immune system has long been recognized, the mechanisms responsible for the initiation of autoimmunity and the role of immune effector pathways in the pathogenesis of SSc remain incompletely understood. This review summarizes recent progress in disease pathogenesis with particular focus on the immunopathogenetic mechanisms of SSc.

Keywords: scleroderma, immune mediators, inflammation, autoimmunity

\section{Introduction}

Systemic sclerosis $(\mathrm{SSc})$ is a rare disease with a prevalence ranging from 150 to 300 cases per million. ${ }^{1,2}$ Although SSc has a worldwide distribution, prevalence varies substantially around the world, with lower estimates ( $<150$ per million) in Northern Europe and Japan and higher estimates (276-443 per million) in Southern Europe, North America, and Australia. ${ }^{2}$ As in many other autoimmune diseases, women are at higher risk than men (4:1 ratio over men), ${ }^{3-5}$ and ethnicity plays a critical role in disease manifestations and mortality. ${ }^{6}$ The etiology of SSc remains elusive, but it likely involves an interaction between environmental factors in a genetic predisposing background. Although SSc is not an inherited disease, ${ }^{7}$ genetic factors contribute to its susceptibility, ${ }^{8,9}$ as shown by a 60 -fold higher occurrence of the disease in families $(1.6 \%)$ than in the general population $(0.026 \%) .{ }^{8}$ Genetic linkage studies and genome-wide association studies have identified polymorphisms associated with the predisposition of patients to develop SSc. ${ }^{10-15}$ These include genes of the major histocompatibility complex (MHC) class II, ${ }^{9,14,16,17}$ as well as non-MHC genes, ${ }^{13,18-24}$ such as genes associated with the metabolism of extracellular matrix (ECM) molecules ${ }^{25-27}$ and genes coding for proteins involved in the control of innate immunity, macrophage activation, and T-cell functions. ${ }^{10,14,28-32}$ Although progress has been made in the identification of genetic risk factors in SSc, the corresponding functional mechanisms remain elusive, except for the contribution of MHC class II to autoantibody specificity. ${ }^{33-38}$ Functional studies of associated loci are thus an area of current focus. Environmental factors have been implicated as early triggers of disease processes. Viruses, including 
human cytomegalovirus, ${ }^{39}$ parvovirus B19, ${ }^{40}$ and EpsteinBarr virus, ${ }^{41}$ are hypothesized to contribute to the development of SSc by inducing vascular damage and fibroblast proliferation. ${ }^{42}$ Other environmental factors, such as drugs as well as environmental and occupational exposures to organic solvents including vinyl chloride, silica, ${ }^{43}$ and nanoparticles from traffic-derived pollution, ${ }^{44}$ have also been implicated as potential causative agents. SSc exhibits an extensive patientto-patient variability. Heterogeneity has been observed in its clinical manifestations, clinical course, response to treatment, and survival. ${ }^{3}$ Based on the extent of skin fibrosis and the pattern of internal organ involvement, patients with SSc are commonly classified into diffuse cutaneous SSc (dcSSc) and limited cutaneous SSc (lcSSc) subsets. ${ }^{45-47}$ Patients with dcSSc have rapidly progressive fibrosis of the skin, lungs, and other internal organs and present early development of visceral organ complications. In contrast, in $1 \mathrm{SSSc}$, the most prominent features are vascular manifestations, with generally mild skin and internal organ fibrosis. Classification criteria for SSc have been recently updated by a joint committee of the American College of Rheumatology and the European League Against Rheumatism. ${ }^{48}$ The American College of Rheumatology/European League Against Rheumatism classification criteria are more sensitive and specific than the previous criteria and now include patients in the early stages of SSc and lcSSc. The expectation is that earlier and more specific diagnosis will enable timely treatment before irreversible organ damage occurs.

\section{Mechanisms of pathogenesis}

The pathogenesis of SSc is poorly understood, which has hampered the development of effective therapeutics for this complex connective tissue disease. Research effort in understanding the key pathogenetic pathways, cell types, and mediators underlying disease manifestations is crucial for the early diagnosis of SSc as well as for the development of targeted therapies. Pathogenesis of SSc is characterized by three hallmarks: small-vessel vasculopathy, dysregulation of innate and adaptive immunity, and extensive fibrosis of the skin and visceral organs. Fibrosis is a major contributor to the high level of morbidity and mortality in SSc and is believed to result from the interaction of immune mediators and other growth factors with responsive tissue fibroblasts, resulting in increased deposition of ECM in the skin and internal organs. ${ }^{49,50}$ Although cutaneous fibrosis is the most characteristic feature of SSc, fibrosis of visceral organs results in organ damage and poor clinical outcome.
Clinical symptoms and histological data indicate that vascular injury and endothelial damage are the earliest pathogenic events in SSc, ${ }^{51,52}$ possibly initiated by viruses, autoantibodies, chemicals, or oxidative products. ${ }^{52,53}$ Activated endothelial cells upregulate the expression of adhesion molecules, ${ }^{54}$ such as vascular cell adhesion protein 1 , intercellular adhesion molecule, and E-selectin, as well as chemokines, such as MCP-1, MIP-1 $\alpha$, and MIP-1 $\beta$, resulting in the recruitment of inflammatory cells. Endothelial cells also produce endothelin-1 and connective tissue growth factor, which stimulate vascular smooth-muscle cell proliferation and ECM production. ${ }^{55,56}$ Progressive thickening of the vessel wall results in a narrowing of the lumen of the capillaries and in the loss of the microvasculature, which leads to tissue hypoxia and oxidative stress. ${ }^{51}$ Moreover, vascular repair and angiogenesis are found defective in SSc, promoting the chronic disease state. ${ }^{57}$ Infiltration of inflammatory cells is prominent in patients with early-stage disease $e^{58,59}$ and is often seen in a perivascular distribution and preceding the development of vasculopathy and fibrosis.

A schematic representation of SSc pathogenesis is illustrated in Figure 1. This review focuses on the immune dysregulation processes associated with SSc pathogenesis and discusses the recent advances.

\section{Immunopathogenesis of SSc}

Immunological abnormalities of innate and adaptive immune system have long been recognized in SSc, including chronic mononuclear cell infiltration of affected tissues, dysregulation of cytokine and growth factor production, and production of autoantibodies. ${ }^{60,61}$ In addition, numerous genetic association studies have identified several polymorphisms in genes relevant for innate and adaptive immune responses that confer susceptibility to SSc. ${ }^{10,14}$ Polymorphisms in genes of the innate immune system include $P L D 4,{ }^{62}$ toll-like receptor (TLR) 2, ${ }^{31}$ NLRP $1,{ }^{63}$ and ATG5. ${ }^{13}$ Other polymorphisms associated with SSc are in genes that play important roles in T-cell differentiation, proliferation, and/or activation. Among those are STAT4, ${ }^{64,65}$ TBX21, ${ }^{65}$ PTPN22, ${ }^{66}$ tumor necrosis factor (TNF)SF4, ${ }^{67,68}$ interleukin (IL)-21, ${ }^{69}$ CD247, ${ }^{28,70}$ and CD226. ${ }^{71}$ Polymorphisms in gene regulators of interferon (IFN) types I and II, such as IFN-regulatory factor $(I R F) 5^{28,72}$ and $I R F 8,{ }^{11}$ are also associated with SSc susceptibility. Other cytokines and chemokine genes associated with SSc include TNFAIP $3,{ }^{73,74} \mathrm{MIF},{ }^{75} \mathrm{IL}-6,{ }^{76} \mathrm{CXCL8},{ }^{77}$ and CCR6. ${ }^{78}$ However, the mechanisms responsible for the initiation of autoimmunity leading to fibrosis and the role of immune effector 


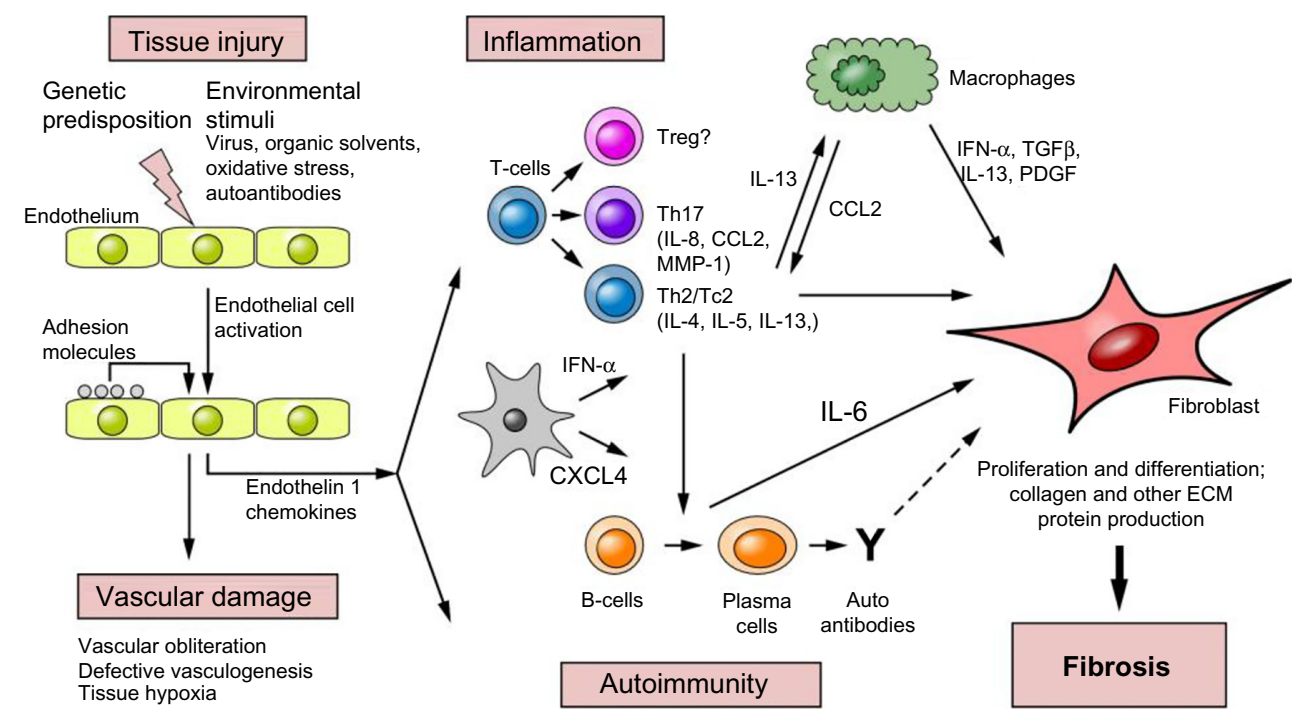

Figure I Etiopathogenesis of SSc.

Notes: Environmental and genetic factors contribute to the etiology of SSc. The pathogenesis of SSc involves an interplay between vascular, immunological, and fibrotic processes. Vascular injury and endothelial damage are the earliest events in the pathogenesis of SSc. Activated endothelial cells upregulate the expression of adhesion molecules and secrete chemokines, leading to inflammation and autoimmunity. Macrophages and T-cells are the predominant inflammatory cell types of the inflammatory infiltrates and produce cytokines and growth factors that drive the synthesis of extracellular matrix proteins by fibroblasts, resulting in progressive fibrosis. T-cells have also been implicated in autoantibodies production.

Abbreviations: ECM, extracellular matrix; IFN, interferon; IL, interleukin; MMP-I, matrix metalloproteinases-I; PDGF, platelet-derived growth factor; SSc, systemic sclerosis; TGF $\beta$, transforming growth factor beta; Treg, T-regulatory cell; ?, role unknown.

pathways in the pathogenesis of SSc remain incompletely understood.

\section{Mononuclear cell infiltrates}

Histological studies indicate that a perivascular inflammatory infiltrate accompanies endothelial cell damage in very early stages of SSc. ${ }^{58,59}$ Macrophages and T-lymphocytes are the predominant inflammatory cell types and are believed to produce cytokines and other immune mediators with proinflammatory and profibrotic function. Interestingly, in situ hybridization studies have demonstrated that collagensynthesizing fibroblasts are located in close proximity to small blood vessels and to the perivascular inflammatory infiltrate, ${ }^{60,79}$ consistent with the hypothesis that inflammatory cells provide important stimuli that drive collagen synthesis in fibroblasts. Indeed, multiple studies in patients with early disease have demonstrated an association between macrophages, inflammation, and skin ${ }^{80}$ and lung fibrosis. ${ }^{81}$ Tissue-resident macrophages become profibrotic through "alternative activation" by type 2 cytokines, such as IL-13 (M2 macrophages), and produce transforming growth factor beta (TGF $\beta$ ) with profibrotic function. ${ }^{82}$ Indeed, increased levels of soluble CD163, a marker for M2 macrophages, were found in the blood and in the affected tissues of patients with early SSc. ${ }^{83}$ Infiltrating T-cells in SSc-affected tissues exhibit increased expression of activation markers and express an oligoclonal T-cell receptor repertoire suggestive of an antigen-driven expansion. ${ }^{84,85}$ While their antigen specificity is not known, T-cell-derived cytokines have been implicated in the induction of fibrosis. ${ }^{86}$ T-cells have also been found necessary for the production of autoantibodies ${ }^{87}$ and in driving inflammatory responses, which can involve concurrently fibroblasts as well as endothelial and epithelial cells. $\mathrm{CD}^{+}$and $\mathrm{CD}^{+} \mathrm{T}$-cell subsets were both found in the skin $^{88}$ and lungs ${ }^{89}$ of patients with SSc. However, we observed that $\mathrm{CD}^{+}$lymphocytes are more abundant than $\mathrm{CD} 4^{+} \mathrm{T}-\mathrm{cells}$ in the skin of patients with early SSc, while in late-stage disease more $\mathrm{CD}^{+}$lymphocytes are found, ${ }^{88}$ suggesting that $\mathrm{CD}^{+} \mathrm{T}$-cells are involved in early disease processes. We and others established that $\mathrm{SSc} \mathrm{CD} 4^{+}$and $\mathrm{CD} 8^{+}$are characterized by a predominant type 2 phenotype ${ }^{86,88}$ and produce type 2 cytokines, such as IL-13. Moreover, we demonstrated that IL-13-producing CD8 ${ }^{+}$lymphocytes are abundant in the skin lesions of patients with early-stage disease and induce a profibrotic phenotype in fibroblasts. ${ }^{88}$ Although Th17 cells have been found in the skin of patients, ${ }^{90}$ several studies indicate that they do not play a direct role in skin fibrosis but contribute in boosting the inflammatory response in SSc. ${ }^{91}$

Dysfunction of T-regulatory cells (Tregs) also seems to contribute to altered immune homeostasis in SSc, with some 
studies implicating a Treg-deficient suppressive function ${ }^{92-94}$ and/or reduced number ${ }^{95-97}$ and other studies indicating a redirected function of Tregs favoring fibrosis. ${ }^{98}$

An activated B-cell signature has been found in lesional skin and affected the lung tissues of patients with SSc, ${ }^{99,100}$ with upregulation of cell-surface expression of CD19 and CD21, ${ }^{101}$ costimulatory molecules, such as CD80 and CD86, ${ }^{101}$ and B-cell activating factor, ${ }^{102}$ a B-cell stimulatory molecule that induces B-cell proliferation, and immunoglobulin secretion. ${ }^{103}$ CD19 associates with CD21 and positively regulates B-cell function. ${ }^{104} \mathrm{CD} 19$ overexpression induces the production of autoantibodies ${ }^{105}$ and skin fibrosis ${ }^{106}$ in transgenic mouse models. Significantly, a single nucleotide polymorphism in the CD19 gene promoter $(-499 \mathrm{G}>\mathrm{T})$ has been associated with higher CD19 expression in B-cells and with susceptibility to $\mathrm{SSc},{ }^{107}$ consistent with a role in B-cell activation in SSc. Furthermore, recent studies have shown that SSc B-cells can induce contact-dependent human dermal fibroblasts activation and upregulation of type I collagen ${ }^{108}$ and that depletion of B-cells in a mouse model of scleroderma led to reduced fibrosis. ${ }^{109}$ Therefore, B-cell activation and overactivity is not only involved in autoantibodies production in SSc but might also contribute to the fibrotic process.

Several recent studies implicate TLR signaling as one of the early steps during inflammatory and fibrotic processes of SSc. ${ }^{110,111}$ TLR activation in SSc innate immune cells is believed to be triggered by microbial and endogenous ligands, such as products released from cells upon damage, necrosis, or stress. ${ }^{110}$ A recent study showed that TLR2 is upregulated in SSc fibroblasts and responds to the acute-phase reactant serum amyloid A, resulting in increased IL-6 secretion by fibroblasts. ${ }^{112,113}$ Interestingly, a rare polymorphism in the gene for TLR2 is associated with the SSc phenotype and induces the production of inflammatory mediators. ${ }^{31}$ TLR4 is overexpressed in SSc skin and lung biopsies, ${ }^{114-116}$ and its levels correlate with progressive skin disease. ${ }^{114}$ Although the canonical ligand of TLR4 is LPS, numerous endogenous ligands have been shown to activate TLR4. ${ }^{117}$ TLR4 can also respond to the alternative spliced fibronectin domain A (Fn-EDA), which is markedly upregulated in response to tissue damage and wound healing. ${ }^{118}$ Interestingly, Fn-EDA was shown to be upregulated in the serum and skin biopsies of patients with SSc. ${ }^{116}$ High levels of Fn-EDA were also found in idiopathic pulmonary fibrosis ${ }^{119}$ and cardiac allograft fibrosis. ${ }^{120}$ Significantly, in vitro and in vivo studies demonstrated that Fn-EDA promoted cutaneous fibrosis through TLR4 signaling, whereas its blockade led to reduced experimental fibrosis, ${ }^{115,116}$ supporting a model of endogenous Fn-EDA-TLR4 signaling axis in cutaneous fibrosis. Intracellular TLRs, such as TLR3, TLR7, TLR8, and TLR9, are sensors for nucleic acids, often of viral origin, ${ }^{121}$ and have been implicated in driving inflammation and fibrosis in SSc. ${ }^{110,111}$ Of interest, Farina et $\mathrm{al}^{41}$ reported an association between Epstein-Barr virus infection of SSc dermal fibroblasts and endothelial cells, activation of TLR, and upregulation of selected IRFs, IFN-stimulated genes, TGF $\beta$, and several markers of fibroblast activation, such as smooth-muscle actin and endothelin-1. These results suggest that persistent injury following a viral infection of nonimmune cells might cause chronic inflammation and fibrosis. TLR activation in SSc immune cells triggers the production of several inflammatory cytokines, particularly type I IFNs. Indeed, an increased gene expression IFN "signature" has been found in peripheral blood mononuclear cells and in the skin of patients with $\mathrm{SSc}^{31,122,123}$ along with evidence suggesting TLR activity in SSc sera. ${ }^{124}$ Moreover, TLR activation of dendritic cells and macrophages also stimulates IL-1, TNF $\alpha$, and IL-6 production, and these or other undefined mediators might drive inflammation and fibrosis in SSc.

\section{Immune mediators}

Several cytokines and growth factors are released by immune cells and are believed to play a critical role in the inflammatory and fibrotic processes of SSc. ${ }^{125,126}$ Abnormal levels of cytokines, such as TGF $\beta,{ }^{127}$ TNF $\alpha$, and IL-6, IL-10, ${ }^{128}$ IL-17, ${ }^{129}$ IL-4, and IL-13, ${ }^{130}$ have been found in the serum and affected tissues of patients with SSc. Among other functions, these cytokines are thought to promote overproduction of collagen by fibroblasts, resulting in excessive fibrosis. ${ }^{131}$ Monocytes and macrophages mainly produce TGF $\beta$, IFN- $\alpha$, IL-13, TNF $\alpha$, and IL-1. Lesional macrophages are also a main source of platelet-derived growth factor (PDGF). Numerous studies have implicated PDGF working in concert with TGF $\beta$ in the development of organ fibrosis in SSc. These findings demonstrated the existence of a TGF $\beta$ and IL- $1 \alpha$-dependent autocrine PDGF-A/PDGF receptor $\alpha$ signaling loop in scleroderma skin and lung fibroblasts, which promotes fibrogenesis. ${ }^{132,133}$

IL-6 is also involved in the pathogenesis of SSc. A recent study reported that serum and skin levels of IL-6 are significantly increased in patients with early dcSSc and that a monoclonal anti-IL-6-receptor antibody prevents the development of bleomycin-induced dermal fibrosis in mice. ${ }^{134}$ A clinical trial with an anti-IL-6-receptor antibody (tocilizumab) in SSc is completed, but the results have not 
been released (NCT01532869). B-cells are a main source of IL-6 in SSc, ${ }^{135}$ but endothelial cells and fibroblasts also produce high levels of IL-6. ${ }^{136}$

Recent studies have focused on TGF $\beta$ and to a lesser extent on IL-13 as major profibrotic factors in the pathogenesis of SSc. Recent advances in these studies are outlined below.

TGF $\beta$ has long been implicated in the pathogenesis of SSc. ${ }^{137}$ Based on extensive in vitro and animal data and the correlation observed between disease activity and increased expression of TGF $\beta$-regulated genes in fibrotic skin and lungs of patients with SSc, ${ }^{137}$ TGF $\beta$ is considered as a key mediator of fibrosis in SSc. TGF $\beta$ promotes collagen synthesis, secretion, processing, and cross-linking, ${ }^{137}$ as well as secretion of other matrix molecules, such as fibronectin and thrombospondin. ${ }^{137}$ Although inhibition of TGF $\beta$ represents an ideal therapeutic approach in $\mathrm{SSc}$, a recent clinical trial using the anti-TGF $\beta$ mAb CAT-192 failed to show any change in skin thickening, measured by the Modified Rodnan Skin Score, between treatment groups. ${ }^{138}$ However, striking results were recently obtained in an open-label trial that used fresolimumab, a high-affinity neutralizing antibody, that targets all three TGF $\beta$ isoforms. ${ }^{139}$ Patients with earlystage dcSSc treated with fresolimumab showed a rapid and significant decrease in Modified Rodnan Skin Score, which correlated closely with the inhibition of TGF $\beta$-regulated gene expression. Thus, this study shows that fresolimumab reverses markers of skin fibrosis and holds promise as a potent antifibrotic agent.

Multiple studies indicate that the immunopathological response in SSc is dominated by type 2 cytokines, such as IL-4 and IL-13. ${ }^{86,126}$ Type 2 cytokines are important regulators of ECM remodeling, leading to enhanced collagen deposition and tissue fibrosis. Animal studies provide support for the role of a polarized immune response in the pathogenesis of fibrosis. ${ }^{140,141}$ Transcriptome analysis in animal models of inflammation has shown that genes involved in wound healing and fibrosis are associated with Th2-polarized responses, ${ }^{142,143}$ and IL-13 was shown to have an important role in the mouse model of bleomycin-induced fibrosis. ${ }^{141}$ Increased levels of type 2 cytokines have been found in the serum and affected tissues of patients, ${ }^{88,125,130}$ and we and others established that T-lymphocytes ${ }^{88}$ and macrophages ${ }^{144}$ are the major cellular source in SSc. We demonstrated that dysregulated production of profibrotic IL-13 by peripheral blood effector CD ${ }^{+}$T-cells correlates with more severe skin thickening in $\mathrm{SSc}^{145}$ and is associated with defects in the molecular control of IL-13 production, such as the aberrant expression of the transcription factor GATA-3. ${ }^{146}$ Circulating $\mathrm{CD}^{+} \mathrm{IL}-13^{+}$T-cells express skin-homing receptors and induce a profibrotic phenotype in normal dermal fibroblasts, which is inhibited by an antiIL-13 antibody. ${ }^{88}$ High number of $\mathrm{CD} 8^{+} \mathrm{IL}-13^{+}$T-cells were also found in the skin lesions of patients, particularly in the early inflammatory phase of the disease ${ }^{88}$ and potentially contributing to the development of sustained profibrotic and inflammatory autoimmune responses. Two Phase II doubleblind, randomized, placebo-controlled trials were started in SSc-related interstitial lung disease (ILD) and IPF with a fully human monoclonal antibody against human IL-13 (Clinical Trial Registration Number: NCT00581997). However, the study was terminated early due to concerns with risks associated with the bronchoscopy procedure involved, and no results ensued.

Chemokines play a crucial role in the inflammatory, vascular, and fibrotic processes of SSc. In all cases, chemokines provide a chemotactic signal to cells by binding to their specific cell-surface receptors. Chemokines, such as CCL18, CCL19, and CXCL13, were found upregulated in the skin of patients with dcSSc. Expression of CCL19 correlated with markers of vascular inflammation and macrophage recruitment and may represent a marker for the perivascular inflammation and immune cell recruitment in dcSSc skin disease. ${ }^{147}$ Serum and tissue levels of CCL2, CCL3, and IL-8 are also increased in patients with SSc and correlate with disease severity and can predict progression. ${ }^{148-150}$ Plasmacytoid dendritic cells from patients were found to secrete high levels of CXCL4 (or platelet factor 4), ${ }^{151}$ a chemokine with antiangiogenic function. Plasma levels of CXCL4 are increased in SSc and correlate with disease severity, ${ }^{151}$ including lung fibrosis and pulmonary arterial hypertension. ${ }^{151} \mathrm{~A}$ recent study shows that the expression and function of CCR1, CCR2, and CCR3 are upregulated in monocytes from patients with SSc via molecular mechanisms involving caveolin-1, Src/Lyn, and MEK/ERK signaling and represent promising targets for novel treatments for fibrotic diseases, such as SSc. ${ }^{152}$

\section{Autoantibodies}

Serum autoantibodies directed against a variety of intracellular antigens are present in nearly all patients and are considered a hallmark of SSc. ${ }^{153}$ Many of these autoantibodies are specific to nuclear antigens and play no role in the pathogenesis of the disease. However, they represent important diagnostic and prognostic agents and exhibit a strong association with distinct clinical subsets, which has been confirmed in many independent patient cohorts. ${ }^{153}$ More recently, autoantibodies 
targeting cell-surface antigens and/or extracellular proteins have been detected in the serum of patients with SSc. These autoantibodies have been shown in some studies to be functional, as they were capable of triggering receptor activation and eliciting profibrotic responses. Several patients have been reported to have circulating autoantibodies against the PDGF receptor. ${ }^{154}$ These antibodies were shown to generate reactive oxygen species and stimulate myofibroblast differentiation and type 1 collagen production. Autoantibodies against the angiotensin II receptor type 1 and endothelin receptor type A have been recently identified in patients with SSc and are believed to stimulate production of IL-18 and CCL18 by mononuclear blood cells. ${ }^{155}$ Antiendothelial cell antibodies have been detected in the sera of some patients with SSc and have been shown to induce endothelial cell apoptosis in vitro. ${ }^{156-158}$ Finally, antibodies against fibroblasts, ${ }^{159,160}$ fibrillin, ${ }^{161}$ and matrix metalloproteinases- $1^{162}$ and $-3^{163}$ were found, which are also believed to carry biological activities.

\section{Immunosuppressive and immunomodulatory therapies in SSc} Therapeutic options in SSc are limited due to the multisystem involvement of this disease and the wide spectrum of clinical features. Current therapeutic strategies include general immunosuppression and organ-based therapies for the improvement of symptoms. More specific therapies for SSc are currently unavailable. Current or completed clinical studies of immunotherapeutic candidates are reported in Table 1 .

Immunosuppressive therapy has been commonly used to control the inflammatory phase of patients with progressive or early-stage disease. However, multiple studies have demonstrated the inefficacy of this therapy in affecting the fibrotic manifestations and the potential for severe secondary effects. Immunosuppressive agents have been used on more aggressive forms of SSc skin disease, such as early dcSSc. ${ }^{164}$ However, no conclusive trials are currently available to guide management of SSc skin involvement. This is due to the lack of sensitive and specific outcome measures and to the normally variable history of SSc. ${ }^{165}$ An improvement in skin score was observed in two multicenter, randomized, controlled trials in which methotrexate ${ }^{166}$ and cyclophosphamide ${ }^{167}$ were used. In addition, two case series at scleroderma centers indicated the efficacy of mycophenolate mofetil in the treatment of skin disease. ${ }^{168,169}$

Immunosuppressive therapy has shown benefits in the treatment of SSc-ILD in those patients with severe lung involvement. Several clinical trials have shown the efficacy of cyclophosphamide in improving ${ }^{167,170,171}$ and/or stabilizing ${ }^{172-176}$ lung function parameters. Other frequently used immunosuppressants in ILD include mycophenolate mofetil and azathioprine. ${ }^{177}$ While immunosuppressive therapy is advised for patients with early stage, progressive SSc, lung transplantation can be considered for end-stage disease. $^{178}$

Imatinib is a powerful inhibitor of PDGF and TGF $\beta$ signaling pathways and has been evaluated in multiple clinical studies to establish effectiveness on skin ${ }^{179,180}$ and lung ${ }^{181,182}$ fibrosis. Outcomes from these studies provided controversial results on efficacy and demonstrated the poor tolerability of this drug. In a recent study, low-dose imatinib was used in a cohort of patients with SSc-ILD with active pulmonary disease and unresponsive to cyclophosphamide. ${ }^{182}$ Of note, $73 \%$ of the 30 patients treated had improved or stabilized pulmonary disease after 6 months' treatment. Despite these encouraging results, the risk/benefit ratio for the use of imatinib needs to be determined in larger controlled trials.

Rituximab, an inhibitor of B-cell function, has also shown promise as a new therapeutic option in various manifestations of SSc, particularly ILD. In an open-label clinical trial, rituximab treatment improved skin scores and preserved the pulmonary function of patients with early progressive dcSSc. ${ }^{183}$ Moreover, rituximab was well tolerated by patients even after repeated courses of treatment. ${ }^{183}$ As no control group was used in this study, a double-blind, randomized control trial is going on to confirm these results. Efficacy on skin thickness and lung function was also observed after rituximab treatment in a case-control study using the European Scleroderma Trial and Research cohort. ${ }^{184}$

Intravenous immunoglobulin (IVIG) is another potential agent for skin involvement. The role of IVIG in SSc is currently unknown. However, IVIG has demonstrated to have immunomodulatory and anti-inflammatory effects in other autoimmune disorders as well as an antifibrotic effect in several animal models. ${ }^{185}$ Multiple courses of IVIG treatment were employed in a multicenter, randomized, controlled clinical trial. ${ }^{186}$ The outcome of this study demonstrated a beneficial effect on skin score. Similarly, improvement in skin involvement was also observed in a single-center retrospective study, in which patients with active refractory dcSSc received monthly courses of IVIG (with or without immunosuppressive therapies). ${ }^{187}$

High-dose immunosuppressive therapy followed by autologous hematopoietic stem-cell transplantation (HSCT) is an emerging treatment option for patients with early progressive SSc who are refractory to conventional 


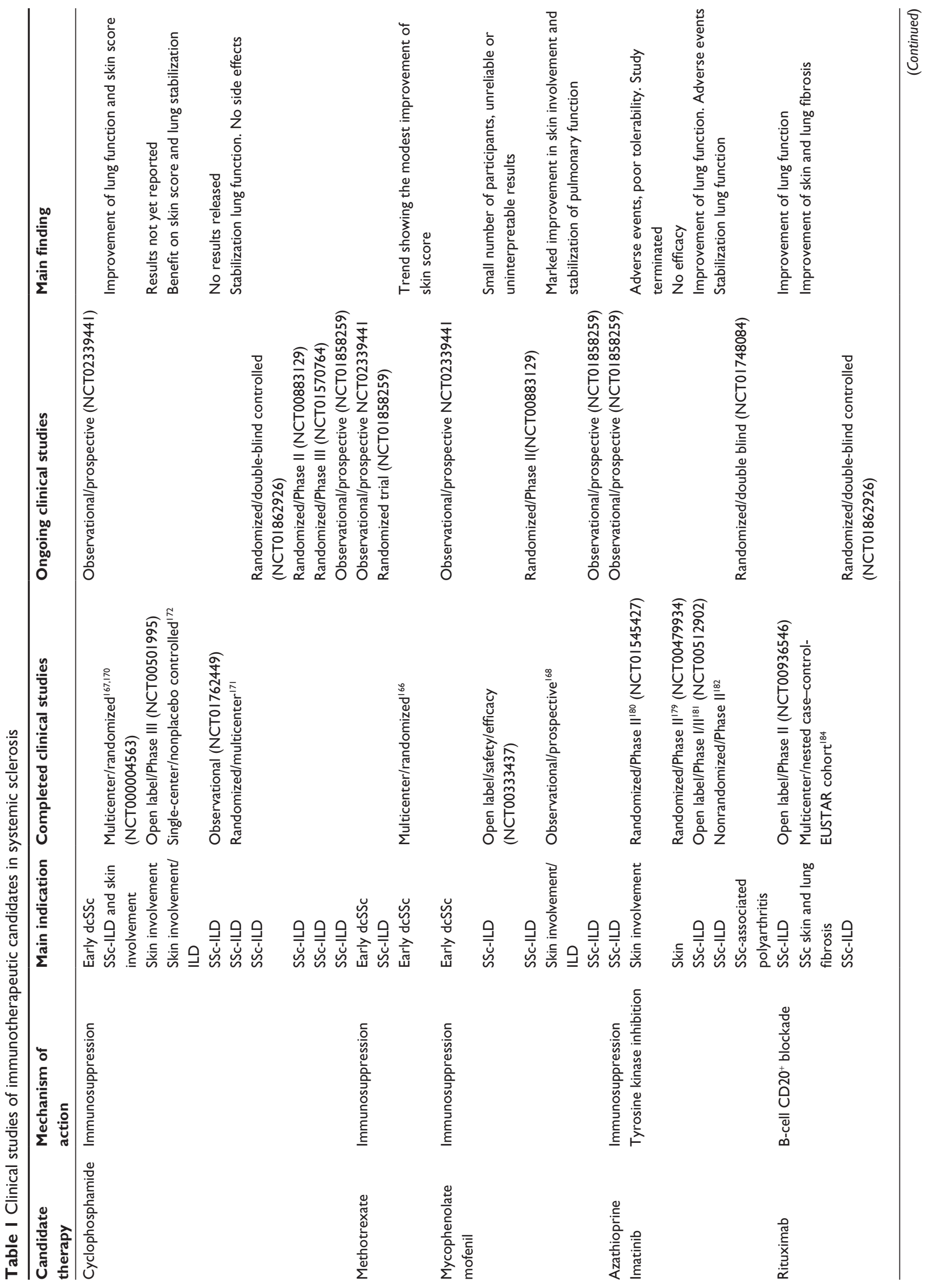




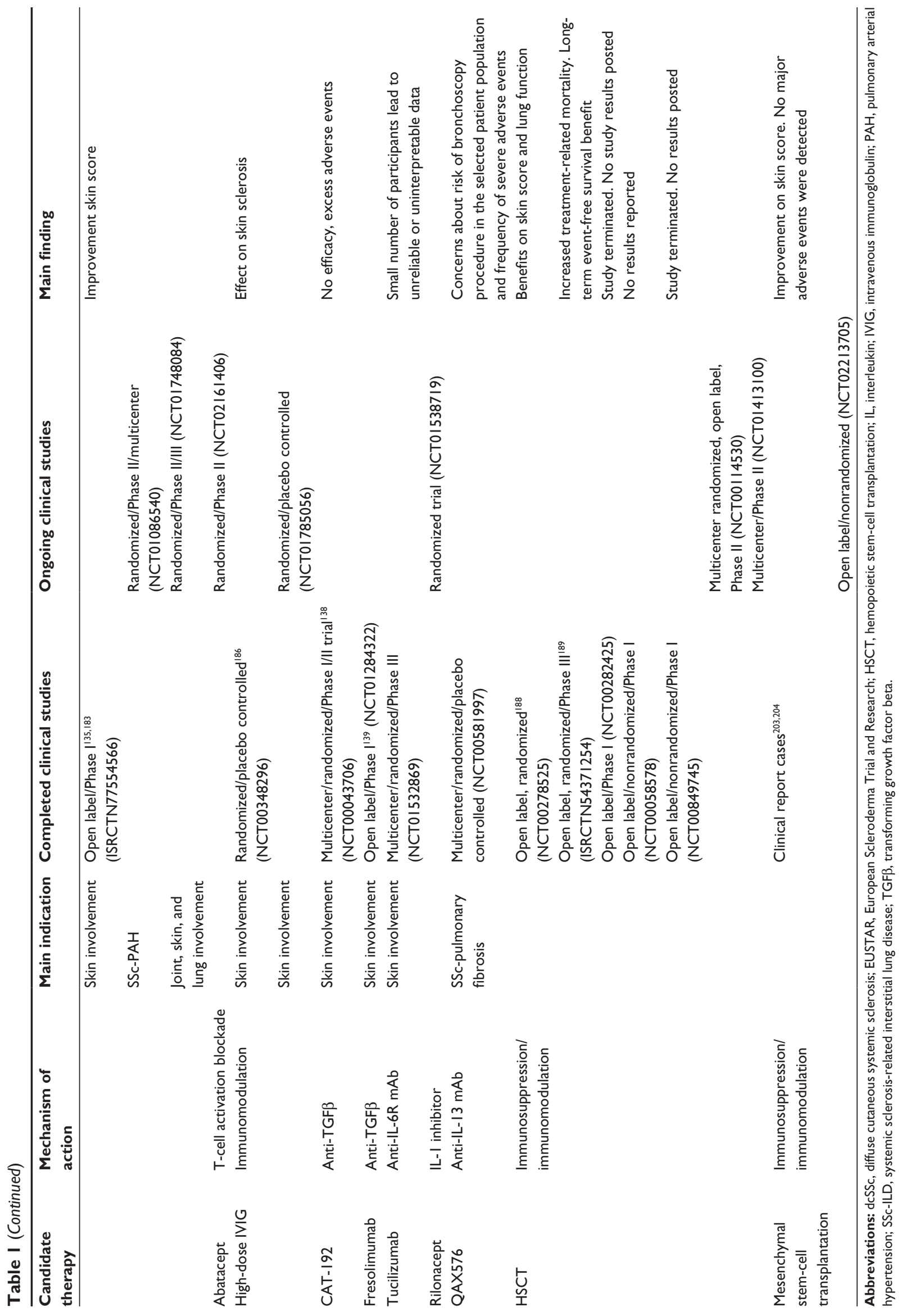


treatments. ${ }^{177-181}$ Clinical trials, such as the American Scleroderma Stem Cell versus Immune Suppression Trial ${ }^{188}$ and the Autologous Stem-Cell Transplantation International Scleroderma trial, ${ }^{189}$ have shown efficacy in preventing disease progression. In both trials, HSCT was shown to cause an improvement in skin and lung involvement as well as vasculopathy and was able to correct immune abnormalities. Despite its potential benefits, HSCT is a dangerous therapeutic option, which is associated with a high risk of treatment-related mortality and an increase in serious adverse events. Its use, therefore, is limited to severe cases of SSc and administered only as a part of a research protocol. Two large multicenter trials are going on. One trial compares monthly intravenous cyclophosphamide to myeloablation with cyclophosphamide and total body irradiation (Scleroderma: Cyclophosphamide or Transplantation) (ClinicalTrials.gov identifier NCT00114530). The second trial (Scleroderma Treatment with Autologous Transplant) includes myeloablation followed by HSC transplantation and long-term immunosuppression (mycophenylate) for dcSSc (ClinicalTrials. gov identifier NCT01413100).

Mesenchymal stem cell (MSC)-based therapy represents an alternative potential therapeutic approach for $\mathrm{SSc}$, with fewer long-term side effects. ${ }^{190-192}$ Several in vitro studies have demonstrated that MSCs display specific immunomodulatory and immunosuppressive properties as well as regenerative potential. ${ }^{193-195}$ Their most important immunosuppressive effects are on T-cell proliferation and dendritic cell differentiation ${ }^{191,192,196-199}$ as well as the production of immunosuppressive mediators, such as TGF $\beta,{ }^{200}$ prostaglandin E2, and indoleamine 2,3-deoxygenase. ${ }^{201}$ A recent report demonstrated that MSCs from patients with SSc while supporting normal hemopoiesis and retaining their immunosuppressive properties on T-cells also exhibit an increased expression of TGF $\beta$ receptor type II compared to MSCs from healthy donors, which leads to increased activation of TGF $\beta$ signaling and synthesis of COL1A1, ${ }^{200,202}$ thereby contributing to SSc pathogenesis. While this defect limits the clinical use of autologous MSCs in SSc, it supports the use of allogeneic MSCs instead. Two recent clinical case studies $^{203,204}$ describe the use of allogeneic MSCs in patients with severe refractory SSc. In one study, a significant decrease in the number of digital ulcers and skin thickness was observed after 3 months and 6 months, respectively, from intravenous injection of a patient with MSCs. ${ }^{203}$ The second study reported skin improvement in two out of the four cases analyzed and observed no major side effects for several months from MSCs' injections. ${ }^{204}$ Although these results are encouraging, no conclusions about the efficacy of allogeneic MSCs in SSc can be yet drawn because of the limited number of patients tested. Moreover, additional studies are necessary to better understand the underlying MSC-immunomodulatory mechanisms as well as the role of MSCs in the pathogenesis of SSc. Furthermore, preclinical and clinical data that underlie the therapeutic potential of MSCs in patients with SSc are also necessary.

\section{Conclusion}

$\mathrm{SSc}$ is a complex multisystem disorder with heterogeneous clinical features that results from individual genetic background and exposure to environmental triggers. Pathogenesis of SSc is dominated by a complex interrelation between vascular, immunologic, and fibrotic processes, and it is poorly understood. Clinical outcomes in SSc have improved considerably in recent years, which may reflect improvements in the early detection and better management of significant complications, such as renal crisis or pulmonary arterial hypertension. However, SSc continues to exhibit high mortality, and it is still considered an incurable disease. Research efforts toward understanding the cellular and molecular basis of scleroderma aim to reveal novel molecular targets and diagnostic agents, leading to early and accurate diagnosis and innovative therapies against this disease. Next-generation sequencing and other cutting-edge technologies applied to affected tissues or cells will be crucial for the identification of biomarkers and pathways that are uniquely expressed in patients and are associated with disease form and/or stage. The development of preclinical models, including animal models that accurately recapitulate human disease, will be essential tools for the ultimate goal of finding a cure for this disease.

Personalized medicine offers interesting opportunities in SSc. Genomic and proteomic studies coupled with novel computational approaches have led to the identification of several biomarker signatures in patients with SSc, ${ }^{15,205-208}$ which allowed the classification of related patients for more specific treatment. Advances in personalized medicine could be used for objective assessment of responses to clinical trials as well as for developing more effective therapies tailored to a patient's genome or to the molecular and cellular contents.

\section{Disclosure}

The author reports no conflicts of interest in this work.

\section{References}

1. Gabrielli A, Avvedimento EV, Krieg T. Scleroderma. N Engl J Med. 2009;360(19):1989-2003. 
2. Barnes J, Mayes MD. Epidemiology of systemic sclerosis: incidence, prevalence, survival, risk factors, malignancy, and environmental triggers. Curr Opin Rheumatol. 2012;24(2):165-170.

3. Medsger TA Jr. Natural history of systemic sclerosis and the assessment of disease activity, severity, functional status, and psychologic well-being. Rheum Dis Clin North Am. 2003;29(2):255-273,vi.

4. Medsger TA Jr. Classification, prognosis. In: Clements PJ, Furst DE, editors. Systemic Sclerosis. 2nd ed. Philadelphia: Lippincott Williams and Williams; 2004:17-28.

5. Mayes MD. Scleroderma epidemiology. Rheum Dis Clin North Am. 2003;29(2):239-254.

6. Gelber AC, Manno RL, Shah AA, et al. Race and association with disease manifestations and mortality in scleroderma: a 20-year experience at the Johns Hopkins Scleroderma Center and review of the literature. Medicine. 2013;92(4):191-205.

7. Feghali-Bostwick C, Medsger TA Jr, Wright TM. Analysis of systemic sclerosis in twins reveals low concordance for disease and high concordance for the presence of antinuclear antibodies. Arthritis Rheum. 2003;48(7):1956-1963.

8. Arnett FC, Cho M, Chatterjee S, Aguilar MB, Reveille JD, Mayes MD. Familial occurrence frequencies and relative risks for systemic sclerosis (scleroderma) in three United States cohorts. Arthritis Rheum. 2001;44(6):1359-1362.

9. Luo Y, Wang Y, Wang Q, Xiao R, Lu Q. Systemic sclerosis: genetics and epigenetics. J Autoimmun. 2013;41:161-167.

10. Ramos PS, Silver RM, Feghali-Bostwick CA. Genetics of systemic sclerosis: recent advances. Curr Opin Rheumatol. 2015;27(6):521-529.

11. Gorlova O, Martin JE, Rueda B, et al. Identification of novel genetic markers associated with clinical phenotypes of systemic sclerosis through a genome-wide association strategy. PLoS Genet. 2011;7(7):e1002178.

12. Martin JE, Assassi S, Diaz-Gallo LM, et al. A systemic sclerosis and systemic lupus erythematosus pan-meta-GWAS reveals new shared susceptibility loci. Hum Mol Genet. 2013;22(19):4021-4029.

13. Mayes MD, Bossini-Castillo L, Gorlova O, et al. Immunochip analysis identifies multiple susceptibility loci for systemic sclerosis. Am J Hum Genet. 2014;94(1):47-61.

14. Jin J, Chou C, Lima M, Zhou D, Zhou X. Systemic sclerosis is a complex disease associated mainly with immune regulatory and inflammatory genes. Open Rheumatol J. 2014;8:29-42.

15. Mahoney JM, Taroni J, Martyanov V, et al. Systems level analysis of systemic sclerosis shows a network of immune and profibrotic pathways connected with genetic polymorphisms. PLoS Comput Biol. 2015;11(1):e1004005.

16. Arnett FC, Gourh P, Shete S, et al. Major histocompatibility complex (MHC) class II alleles, haplotypes and epitopes which confer susceptibility or protection in systemic sclerosis: analyses in 1300 Caucasian, African-American and Hispanic cases and 1000 controls. Ann Rheum Dis. 2010;69(5):822-827.

17. Gladman DD, Kung TN, Siannis F, Pellett F, Farewell VT, Lee P. HLA markers for susceptibility and expression in scleroderma. J Rheumatol. 2005;32(8):1481-1487.

18. Pattanaik D, Brown M, Postlethwaite BC, Postlethwaite AE. Pathogenesis of systemic sclerosis. Front Immunol. 2015;6:272.

19. Agarwal SK. The genetics of systemic sclerosis. Discov Med. 2010;10(51):134-143.

20. Martin JE, Bossini-Castillo L, Martin J. Unraveling the genetic component of systemic sclerosis. Hum Genet. 2012;131(7):1023-1037.

21. Zochling J, Newell F, Charlesworth JC, et al. An Immunochip-based interrogation of scleroderma susceptibility variants identifies a novel association at DNASE1L3. Arthritis Res Ther. 2014;16(5):438.

22. Allanore Y, Saad M, Dieudé P, et al. Genome-wide scan identifies TNIP1, PSORS1C1, and RHOB as novel risk loci for systemic sclerosis. PLoS Genet. 2011;7(7):e1002091.

23. Bossini-Castillo L, Martin JE, Broen J, et al. Confirmation of TNIP1 but not RHOB and PSORS1C1 as systemic sclerosis risk factors in a large independent replication study. Ann Rheum Dis. 2013;72(4):602-607.
24. Assassi S, Radstake TR, Mayes MD, Martin J. Genetics of scleroderma: implications for personalized medicine? BMC Med. 2013;11:9.

25. Fonseca C, Lindahl GE, Ponticos M, et al. A polymorphism in the CTGF promoter region associated with systemic sclerosis. $N$ Engl $J$ Med. 2007;357(12):1210-1220.

26. Salazar G, Mayes MD. Genetics, epigenetics, and genomics of systemic sclerosis. Rheum Dis Clin North Am. 2015;41(3):345-366.

27. Wipff J, Dieude P, Avouac J, et al. Association of metalloproteinase gene polymorphisms with systemic sclerosis in the European Caucasian population. J Rheumatol. 2010;37(3):599-602.

28. Radstake TR, Gorlova O, Rueda B, et al. Genome-wide association study of systemic sclerosis identifies CD247 as a new susceptibility locus. Nat Genet. 2010;42(5):426-429.

29. López-Isac E, Bossini-Castillo L, Simeon CP, et al. A genome-wide association study follow-up suggests a possible role for PPARG in systemic sclerosis susceptibility. Arthritis Res Ther. 2014;16(1):R6.

30. López-Isac E, Bossini-Castillo L, Guerra SG, et al. Identification of IL12RB1 as a novel systemic sclerosis susceptibility locus. Arthritis Rheumatol. 2014;66(12):3521-3523.

31. Broen JC, Bossini-Castillo L, van Bon L, et al. A rare polymorphism in the gene for Toll-like receptor 2 is associated with systemic sclerosis phenotype and increases the production of inflammatory mediators. Arthritis Rheum. 2012;64(1):264-271.

32. Arismendi M, Giraud M, Ruzehaji N, et al. Identification of NF-kappaB and PLCL2 as new susceptibility genes and highlights on a potential role of IRF8 through interferon signature modulation in systemic sclerosis. Arthritis Res Ther. 2015;17:71.

33. Reveille JD, Owerbach D, Goldstein R, Moreda R, Isern RA, Arnett FC. Association of polar amino acids at position 26 of the HLA-DQB1 first domain with the anticentromere autoantibody response in systemic sclerosis (scleroderma). J Clin Invest. 1992;89(4):1208-1213.

34. Reveille JD, Durban E, MacLeod-St Clair MJ, et al. Association of amino acid sequences in the HLA-DQB1 first domain with antitopoisomerase I autoantibody response in scleroderma (progressive systemic sclerosis). J Clin Invest. 1992;90(3):973-980.

35. Kuwana M, Okano Y, Kaburaki J, Inoko H. HLA class II genes associated with anticentromere antibody in Japanese patients with systemic sclerosis (scleroderma). Ann Rheum Dis. 1995;54(12):983-987.

36. Falkner D, Wilson J, Fertig N, Clawson K, Medsger TA Jr, Morel PA. Studies of HLA-DR and DQ alleles in systemic sclerosis patients with autoantibodies to RNA polymerases and U3-RNP (fibrillarin). J Rheumatol. 2000;27(5):1196-1202.

37. Johnson RW, Tew MB, Arnett FC. The genetics of systemic sclerosis. Curr Rheumatol Rep. 2002;4(2):99-107.

38. Nguyen B, Mayes MD, Arnett FC, et al. HLA-DRB1*0407 and *1304 are risk factors for scleroderma renal crisis. Arthritis Rheum. 2011;63(2):530-534.

39. Lunardi C, Bason C, Navone R, et al. Systemic sclerosis immunoglobulin $\mathrm{G}$ autoantibodies bind the human cytomegalovirus late protein UL94 and induce apoptosis in human endothelial cells. Nat Med. 2000;6(10):1183-1186.

40. Zakrzewska K, Corcioli F, Carlsen KM, et al. Human parvovirus B19 (B19V) infection in systemic sclerosis patients. Intervirology. 2009;52(5):279-282.

41. Farina A, Cirone M, York M, et al. Epstein-Barr virus infection induces aberrant TLR activation pathway and fibroblast-myofibroblast conversion in scleroderma. J Invest Dermatol. 2014;134(4):954-964.

42. Ferri C, Giuggioli D, Colaci M. Viral infections and systemic sclerosis. Clin Exp Rheumatol. 2014;32(6 suppl 86):S-229.

43. Nietert PJ, Silver RM. Systemic sclerosis: environmental and occupational risk factors. Curr Opin Rheumatol. 2000;12(6):520-526.

44. Mastrofrancesco A, Alfè M, Rosato E, et al. Proinflammatory effects of diesel exhaust nanoparticles on scleroderma skin cells. J Immunol Res. 2014;2014:138751.

45. LeRoy EC, Black C, Fleischmajer R, et al. Scleroderma (systemic sclerosis): classification, subsets and pathogenesis. J Rheumatol. 1988;15(2):202-205. 
46. LeRoy EC, Medsger TA Jr. Criteria for the classification of early systemic sclerosis. J Rheumatol. 2001;28(7):1573-1576.

47. Ingegnoli F, Gualtierotti R. A systematic overview on the use and relevance of capillaroscopy in systemic sclerosis. Expert Rev Clin Immunol. 2013;9(11):1091-1097.

48. van den Hoogen F, Khanna D, Fransen J, et al. 2013 classification criteria for systemic sclerosis: an American College of Rheumatology/European League against Rheumatism collaborative initiative. Arthritis Rheum. 2013;65(11):2737-2747.

49. Katsumoto TR, Whitfield ML, Connolly MK. The pathogenesis of systemic sclerosis. Annu Rev Pathol. 2011;6:509-537.

50. Jinnin M. Mechanisms of skin fibrosis in systemic sclerosis. J Dermatol. 2010;37(1):11-25.

51. Trojanowska M. Cellular and molecular aspects of vascular dysfunction in systemic sclerosis. Nat Rev Rheumatol. 2010;6(8):453-460.

52. Varga J, Abraham D. Systemic sclerosis: a prototypic multisystem fibrotic disorder. J Clin Invest. 2007;117(3):557-567.

53. Kahaleh MB. Raynaud phenomenon and the vascular disease in scleroderma. Curr Opin Rheumatol. 2004;16(6):718-722.

54. Gruschwitz M, von den Driesch P, Kellner I, Hornstein OP, Sterry W. Expression of adhesion proteins involved in cell-cell and cell-matrix interactions in the skin of patients with progressive systemic sclerosis J Am Acad Dermatol. 1992;27(2 Pt 1):169-177.

55. Kawaguchi Y, Suzuki K, Hara M, et al. Increased endothelin-1 production in fibroblasts derived from patients with systemic sclerosis. Ann Rheum Dis. 1994;53(8):506-510.

56. Shi-Wen X, Denton CP, Dashwood MR, et al. Fibroblast matrix gene expression and connective tissue remodeling: role of endothelin-1. J Invest Dermatol. 2001;116(3):417-425.

57. Cipriani P, Di Benedetto P, Capece D, et al. Impaired Cav-1 expression in SSc mesenchymal cells upregulates VEGF signaling: a link between vascular involvement and fibrosis. Fibrogenesis Tissue Repair. 2014;7:13.

58. Roumm AD, Whiteside TL, Medsger TA Jr, Rodnan GP. Lymphocytes in the skin of patients with progressive systemic sclerosis Quantification, subtyping, and clinical correlations. Arthritis Rheum. 1984;27(6):645-653.

59. Fleischmajer R, Perlish JS, Reeves JR. Cellular infiltrates in scleroderma skin. Arthritis Rheum. 1977;20(4):975-984.

60. Jimenez SA, Derk CT. Following the molecular pathways toward an understanding of the pathogenesis of systemic sclerosis. Ann Intern Med. 2004;140(1):37-50.

61. Sakkas LI, Platsoucas CD. Is systemic sclerosis an antigen-driven T cell disease? Arthritis Rheum. 2004;50(6):1721-1733.

62. Terao C, Ohmura K, Kawaguchi Y, et al. PLD4 as a novel susceptibility gene for systemic sclerosis in a Japanese population. Arthritis Rheum. 2013;65(2):472-480.

63. Dieudé P, Guedj M, Wipff J, et al. NLRP1 influences the systemic sclerosis phenotype: a new clue for the contribution of innate immunity in systemic sclerosis-related fibrosing alveolitis pathogenesis. Ann Rheum Dis. 2011;70(4):668-674.

64. Rueda B, Broen J, Simeon C, et al. The STAT4 gene influences the genetic predisposition to systemic sclerosis phenotype. Hum Mol Genet. 2009;18(11):2071-2077.

65. Gourh P, Agarwal SK, Divecha D, et al. Polymorphisms in TBX21 and STAT4 increase the risk of systemic sclerosis: evidence of possible gene-gene interaction and alterations in Th1/Th2 cytokines. Arthritis Rheum. 2009;60(12):3794-3806.

66. Rieck M, Arechiga A, Onengut-Gumuscu S, Greenbaum C, Concannon P, Buckner JH. Genetic variation in PTPN22 corresponds to altered function of T and B lymphocytes. J Immunol. 2007;179(7):4704-4710.

67. Gourh P, Arnett FC, Tan FK, et al. Association of TNFSF4 (OX40L) polymorphisms with susceptibility to systemic sclerosis. Ann Rheum Dis. 2010;69(3):550-555.

68. Bossini-Castillo L, Broen JC, Simeon CP, et al. A replication study confirms the association of TNFSF4 (OX40L) polymorphisms with systemic sclerosis in a large European cohort. Ann Rheum Dis. 2011;70(4):638-641.
69. Diaz-Gallo LM, Simeon CP, Broen JC, et al. Implication of IL-2/IL-21 region in systemic sclerosis genetic susceptibility. Ann Rheum Dis. 2013;72(7):1233-1238.

70. Dieudé P, Boileau C, Guedj M, et al. Independent replication establishes the CD247 gene as a genetic systemic sclerosis susceptibility factor. Ann Rheum Dis. 2011;70(9):1695-1696.

71. Dieudé P, Guedj M, Truchetet ME, et al. Association of the CD226 Ser(307) variant with systemic sclerosis: evidence of a contribution of costimulation pathways in systemic sclerosis pathogenesis. Arthritis Rheum. 2011;63(4):1097-1105.

72. Dieude P, Dawidowicz K, Guedj M, et al. Phenotype-haplotype correlation of IRF5 in systemic sclerosis: role of 2 haplotypes in disease severity. J Rheumatol. 2010;37(5):987-992.

73. Dieudé P, Guedj M, Wipff J, et al. Association of the TNFAIP3 rs5029939 variant with systemic sclerosis in the European Caucasian population. Ann Rheum Dis. 2010;69(11):1958-1964.

74. Koumakis E, Giraud M, Dieudé P, et al. Brief report: candidate gene study in systemic sclerosis identifies a rare and functional variant of the TNFAIP3 locus as a risk factor for polyautoimmunity. Arthritis Rheum. 2012;64(8):2746-2752.

75. Wu SP, Leng L, Feng Z, et al. Macrophage migration inhibitory factor promoter polymorphisms and the clinical expression of scleroderma. Arthritis Rheum. 2006;54(11):3661-3669.

76. Cénit MC, Simeón CP, Vonk MC, et al. Influence of the IL6 gene in susceptibility to systemic sclerosis. J Rheumatol. 2012;39(12):2294-2302.

77. Salim PH, Jobim M, Bredemeier M, et al. Combined effects of CXCL8 and CXCR2 gene polymorphisms on susceptibility to systemic sclerosis. Cytokine. 2012;60(2):473-477.

78. Koumakis E, Bouaziz M, Dieudé P, et al. A regulatory variant in CCR6 is associated with susceptibility to antitopoisomerase-positive systemic sclerosis. Arthritis Rheum. 2013;65(12):3202-3208.

79. Scharffetter K, Lankat-Buttgereit B, Krieg T. Localization of collagen mRNA in normal and scleroderma skin by in-situ hybridization. Eur $J$ Clin Invest. 1988;18(1):9-17.

80. Higashi-Kuwata N, Jinnin M, Makino T, et al. Characterization of monocyte/macrophage subsets in the skin and peripheral blood derived from patients with systemic sclerosis. Arthritis Res Ther. 2010;12(4):R128

81. Christmann RB, Sampaio-Barros P, Stifano G, et al. Association of Interferon- and transforming growth factor beta-regulated genes and macrophage activation with systemic sclerosis-related progressive lung fibrosis. Arthritis Rheumatol. 2014;66(3):714-725.

82. Murray PJ, Allen JE, Biswas SK, et al. Macrophage activation and polarization: nomenclature and experimental guidelines. Immunity. 2014;41(1):14-20.

83. Nakayama W, Jinnin M, Makino K, et al. Serum levels of soluble CD163 in patients with systemic sclerosis. Rheumatol Int. 2012; 32(2):403-407.

84. Sakkas LI, Xu B, Artlett CM, Lu S, Jimenez SA, Platsoucas CD. Oligoclonal $\mathrm{T}$ cell expansion in the skin of patients with systemic sclerosis. J Immunol. 2002;168(7):3649-3659.

85. Kalogerou A, Gelou E, Mountantonakis S, Settas L, Zafiriou E, Sakkas L. Early T cell activation in the skin from patients with systemic sclerosis. Ann Rheum Dis. 2005;64(8):1233-1235.

86. Chizzolini C. T cells, B cells, and polarized immune response in the pathogenesis of fibrosis and systemic sclerosis. Curr Opin Rheumatol. 2008;20(6):707-712.

87. Kuwana M, Medsger TA Jr, Wright TM. T and B cell collaboration is essential for the autoantibody response to DNA topoisomerase I in systemic sclerosis. J Immunol. 1995;155(5):2703-2714.

88. Fuschiotti P, Larregina AT, Ho J, Feghali-Bostwick C, Medsger TA, Jr. Interleukin-13-producing CD8+ T cells mediate dermal fibrosis in patients with systemic sclerosis. Arthritis Rheum. 2013;65(1): $236-246$.

89. Luzina IG, Atamas SP, Wise R, et al. Occurrence of an activated, profibrotic pattern of gene expression in lung $\mathrm{CD} 8+\mathrm{T}$ cells from scleroderma patients. Arthritis Rheum. 2003;48(8):2262-2274. 
90. Truchetet ME, Brembilla NC, Montanari E, et al. Interleukin-17A+ cell counts are increased in systemic sclerosis skin and their number is inversely correlated with the extent of skin involvement. Arthritis Rheum. 2013;65(5):1347-1356.

91. Brembilla NC, Montanari E, Truchetet ME, Raschi E, Meroni P, Chizzolini C. Th17 cells favor inflammatory responses while inhibiting type I collagen deposition by dermal fibroblasts: differential effects in healthy and systemic sclerosis fibroblasts. Arthritis Res Ther. 2013;15(5):R151.

92. Radstake TR, van Bon L, Broen J, et al. Increased frequency and compromised function of T regulatory cells in systemic sclerosis (SSc) is related to a diminished CD69 and TGFbeta expression. PLoS One. 2009;4(6):e5981.

93. Antiga E, Quaglino P, Bellandi S, et al. Regulatory T cells in the skin lesions and blood of patients with systemic sclerosis and morphoea. Br J Dermatol. 2010;162(5):1056-1063.

94. Slobodin G, Ahmad MS, Rosner I, et al. Regulatory T cells (CD4(+) CD25(bright)FoxP3(+)) expansion in systemic sclerosis correlates with disease activity and severity. Cell Immunol. 2010;261(2):77-80.

95. Mathian A, Parizot C, Dorgham K, et al. Activated and resting regulatory T cell exhaustion concurs with high levels of interleukin-22 expression in systemic sclerosis lesions. Ann Rheum Dis. 2012;71(7):1227-1234.

96. Klein S, Kretz CC, Ruland V, et al. Reduction of regulatory T cells in skin lesions but not in peripheral blood of patients with systemic scleroderma. Ann Rheum Dis. 2011;70(8):1475-1481.

97. Wang YY, Wang Q, Sun XH, et al. DNA hypermethylation of the forkhead box protein 3 (FOXP3) promoter in CD4+ T cells of patients with systemic sclerosis. Br J Dermatol. 2014;171(1):39-47.

98. MacDonald KG, Dawson NA, Huang Q, Dunne JV, Levings MK, Broady R. Regulatory $\mathrm{T}$ cells produce profibrotic cytokines in the skin of patients with systemic sclerosis. J Allergy Clin Immunol. 2015;135(4):e946-e949.

99. Whitfield ML, Finlay DR, Murray JI, et al. Systemic and cell typespecific gene expression patterns in scleroderma skin. Proc Natl Acad Sci US A. 2003;100(21):12319-12324.

100. Lafyatis R, O'Hara C, Feghali-Bostwick CA, Matteson E. B cell infiltration in systemic sclerosis-associated interstitial lung disease. Arthritis Rheum. 2007;56(9):3167-3168.

101. Sato S, Fujimoto M, Hasegawa M, Takehara K. Altered blood B lymphocyte homeostasis in systemic sclerosis: expanded naive B cells and diminished but activated memory B cells. Arthritis Rheum. 2004;50(6):1918-1927.

102. Matsushita T, Hasegawa M, Yanaba K, Kodera M, Takehara K, Sato S. Elevated serum BAFF levels in patients with systemic sclerosis: enhanced BAFF signaling in systemic sclerosis B lymphocytes. Arthritis Rheum. 2006;54(1):192-201.

103. Mackay F, Browning JL. BAFF: a fundamental survival factor for B cells. Nat Rev Immunol. 2002;2(7):465-475.

104. Tedder TF, Inaoki M, Sato S. The CD19-CD21 complex regulates signal transduction thresholds governing humoral immunity and autoimmunity. Immunity. 1997;6(2):107-118.

105. Sato S, Hasegawa M, Fujimoto M, Tedder TF, Takehara K. Quantitative genetic variation in CD19 expression correlates with autoimmunity. J Immunol. 2000;165(11):6635-6643.

106. Yoshizaki A, Iwata Y, Komura K, et al. CD19 regulates skin and lung fibrosis via Toll-like receptor signaling in a model of bleomycininduced scleroderma. Am J Pathol. 2008;172(6):1650-1663.

107. Tsuchiya N, Kuroki K, Fujimoto M, et al. Association of a functional CD19 polymorphism with susceptibility to systemic sclerosis. Arthritis Rheum. 2004;50(12):4002-4007.

108. Francois A, Chatelus E, Wachsmann D, et al. B lymphocytes and B-cell activating factor promote collagen and profibrotic markers expression by dermal fibroblasts in systemic sclerosis. Arthritis Res Ther. 2013;15(5):R168.

109. Hasegawa M, Hamaguchi Y, Yanaba K, et al. B-lymphocyte depletion reduces skin fibrosis and autoimmunity in the tight-skin mouse model for systemic sclerosis. Am J Pathol. 2006;169(3):954-966.
110. Bhattacharyya S, Varga J. Emerging roles of innate immune signaling and toll-like receptors in fibrosis and systemic sclerosis. Curr Rheumatol Rep. 2015;17(1):474.

111. Fullard N, O'Reilly S. Role of innate immune system in systemic sclerosis. Semin Immunopathol. 2015;37(5):511-517.

112. O'Reilly S, Cant R, Ciechomska M, et al. Serum amyloid A induces interleukin-6 in dermal fibroblasts via Toll-like receptor 2, interleukin-1 receptor-associated kinase 4 and nuclear factor-kappaB. Immunology. 2014;143(3):331-340

113. Lakota K, Carns M, Podlusky S, et al. Serum amyloid A is a marker for pulmonary involvement in systemic sclerosis. PLoS One. 2015;10(1):e0110820.

114. Stifano G, Affandi AJ, Mathes AL, et al. Chronic Toll-like receptor 4 stimulation in skin induces inflammation, macrophage activation, transforming growth factor beta signature gene expression, and fibrosis. Arthritis Res Ther. 2014;16(4):R136.

115. Bhattacharyya S, Kelley K, Melichian DS, et al. Toll-like receptor 4 signaling augments transforming growth factor-beta responses: a novel mechanism for maintaining and amplifying fibrosis in scleroderma. Am J Pathol. 2013;182(1):192-205.

116. Bhattacharyya S, Tamaki Z, Wang W, et al. FibronectinEDA promotes chronic cutaneous fibrosis through Toll-like receptor signaling. Sci Transl Med. 2014;6(232):232ra250.

117. Chen GY, Nuñez G. Sterile inflammation: sensing and reacting to damage. Nat Rev Immunol. 2010;10(12):826-837.

118. Okamura Y, Watari M, Jerud ES, et al. The extra domain A of fibronectin activates Toll-like receptor 4. J Biol Chem. 2001; 276(13):10229-10233.

119. Muro AF, Moretti FA, Moore BB, et al. An essential role for fibronectin extra type III domain A in pulmonary fibrosis. Am J Respir Crit Care Med. 2008;177(6):638-645.

120. Booth AJ, Wood SC, Cornett AM, et al. Recipient-derived EDA fibronectin promotes cardiac allograft fibrosis. J Pathol. 2012;226(4):609-618

121. Kawai T, Akira S. Toll-like receptors and their crosstalk with other innate receptors in infection and immunity. Immunity. 2011;34(5):637-650.

122. Tan FK, Zhou X, Mayes MD, et al. Signatures of differentially regulated interferon gene expression and vasculotrophism in the peripheral blood cells of systemic sclerosis patients. Rheumatology. 2006;45(6):694-702.

123. York MR, Nagai T, Mangini AJ, Lemaire R, van Seventer JM, Lafyatis R. A macrophage marker, Siglec-1, is increased on circulating monocytes in patients with systemic sclerosis and induced by type I interferons and toll-like receptor agonists. Arthritis Rheum. 2007;56(3):1010-1020.

124. Kim D, Peck A, Santer D, et al. Induction of interferon-alpha by scleroderma sera containing autoantibodies to topoisomerase I: association of higher interferon-alpha activity with lung fibrosis. Arthritis Rheum. 2008;58(7):2163-2173.

125. Baraut J, Michel L, Verrecchia F, Farge D. Relationship between cytokine profiles and clinical outcomes in patients with systemic sclerosis. Autoimmun Rev. 2010;10(2):65-73.

126. Fuschiotti P. Role of IL-13 in systemic sclerosis. Cytokine. 2011;56(3):544-549.

127. Denton CP, Abraham DJ. Transforming growth factor-beta and connective tissue growth factor: key cytokines in scleroderma pathogenesis. Curr Opin Rheumatol. 2001;13(6):505-511.

128. Sato S, Hasegawa M, Takehara K. Serum levels of interleukin-6 and interleukin-10 correlate with total skin thickness score in patients with systemic sclerosis. J Dermatol Sci. 2001;27(2):140-146.

129. Kurasawa K, Hirose K, Sano H, et al. Increased interleukin-17 production in patients with systemic sclerosis. Arthritis Rheum. 2000;43(11):2455-2463.

130. Hasegawa M, Fujimoto M, Kikuchi K, Takehara K. Elevated serum levels of interleukin 4 (IL-4), IL-10, and IL-13 in patients with systemic sclerosis. J Rheumatol. 1997;24(2):328-332. 
131. Kissin EY, Korn JH. Fibrosis in scleroderma. Rheum Dis Clin North Am. 2003;29(2):351-369.

132. Bonner JC. Regulation of PDGF and its receptors in fibrotic diseases. Cytokine Growth Factor Rev. 2004;15(4):255-273.

133. Trojanowska M. Role of PDGF in fibrotic diseases and systemic sclerosis. Rheumatology. 2008;47(supp1 5):v2-v4.

134. Desallais L, Avouac J, Fréchet M, et al. Targeting IL-6 by both passive or active immunization strategies prevents bleomycin-induced skin fibrosis. Arthritis Res Ther. 2014;16(4):R157.

135. Bosello SL, De Luca G, Rucco M, et al. Long-term efficacy of B cell depletion therapy on lung and skin involvement in diffuse systemic sclerosis. Semin Arthritis Rheum. 2015;44(4):428-436.

136. Koch AE, Kronfeld-Harrington LB, Szekanecz Z, et al. In situ expression of cytokines and cellular adhesion molecules in the skin of patients with systemic sclerosis. Their role in early and late disease. Pathobiology. 1993;61(5-6):239-246.

137. Lafyatis R. Transforming growth factor beta - at the centre of systemic sclerosis. Nat Rev Rheumatol. 2014;10(12):706-719.

138. Denton CP, Merkel PA, Furst DE, et al. Recombinant human antitransforming growth factor beta1 antibody therapy in systemic sclerosis: a multicenter, randomized, placebo-controlled phase I/II trial of CAT-192. Arthritis Rheum. 2007;56(1):323-333.

139. Rice LM, Padilla CM, McLaughlin SR, et al. Fresolimumab treatment decreases biomarkers and improves clinical symptoms in systemic sclerosis patients. J Clin Invest. 2015;125(7):2795-2807.

140. Lakos G, Melichian D, Wu M, Varga J. Increased bleomycin-induced skin fibrosis in mice lacking the Th1-specific transcription factor T-bet. Pathobiology. 2006;73(5):224-237.

141. Aliprantis AO, Wang J, Fathman JW, et al. Transcription factor T-bet regulates skin sclerosis through its function in innate immunity and via IL-13. Proc Natl Acad Sci U SA. 2007;104(8):2827-2830.

142. Hoffmann KF, McCarty TC, Segal DH, et al. Disease fingerprinting with cDNA microarrays reveals distinct gene expression profiles in lethal type 1 and type 2 cytokine-mediated inflammatory reactions. FASEB J. 2001;15(13):2545-2547.

143. Sandler NG, Mentink-Kane MM, Cheever AW, Wynn TA. Global gene expression profiles during acute pathogen-induced pulmonary inflammation reveal divergent roles for Th1 and Th2 responses in tissue repair. J Immunol. 2003;171(7):3655-3667.

144. Greenblatt MB, Sargent JL, Farina G, et al. Interspecies comparison of human and murine scleroderma reveals IL-13 and CCL2 as disease subset-specific targets. Am J Pathol. 2012;180(3):1080-1094.

145. Fuschiotti P, Medsger TA Jr, Morel PA. Effector CD8+ T cells in systemic sclerosis patients produce abnormally high levels of interleukin-13 associated with increased skin fibrosis. Arthritis Rheum. 2009;60(4):1119-1128

146. Medsger TA Jr, Ivanco DE, Kardava L, Morel PA, Lucas MR, Fuschiotti P. GATA-3 upregulation in CD8+ T cells is a biomarker of immune dysfunction in systemic sclerosis, resulting in excess IL-13 production. Arthritis Rheum. 2011;63(6):1738-1747.

147. Mathes AL, Christmann RB, Stifano G, et al. Global chemokine expression in systemic sclerosis (SSc): CCL19 expression correlates with vascular inflammation in SSc skin. Ann Rheum Dis. 2014;73(10):1864-1872.

148. Bandinelli F, Del Rosso A, Gabrielli A, et al. CCL2, CCL3 and CCL5 chemokines in systemic sclerosis: the correlation with SSc clinical features and the effect of prostaglandin E1 treatment. Clin Exp Rheumatol. 2012;30(2 Suppl 71):S44-S49.

149. Hasegawa M, Asano Y, Endo H, et al. Serum chemokine levels as prognostic markers in patients with early systemic sclerosis: a multicenter, prospective, observational study. Mod Rheumatol. 2013;23(6):1076-1084.

150. Tiev KP, Hua-Huy T, Kettaneh A, et al. Serum CC chemokine ligand-18 predicts lung disease worsening in systemic sclerosis. Eur Respir J. 2011;38(6):1355-1360.

151. van Bon L, Affandi AJ, Broen J, et al. Proteome-wide analysis and CXCL4 as a biomarker in systemic sclerosis. $N$ Engl $J$ Med. 2014;370(5):433-443.
152. Lee R, Reese C, Perry B, et al. Enhanced chemokine-receptor expression, function, and signaling in healthy African American and scleroderma-patient monocytes are regulated by caveolin-1. Fibrogenesis Tissue Repair. 2015;8:11.

153. Steen VD. Autoantibodies in systemic sclerosis. Semin Arthritis Rheum. 2005;35(1):35-42.

154. Baroni SS, Santillo M, Bevilacqua F, et al. Stimulatory autoantibodies to the PDGF receptor in systemic sclerosis. $N$ Engl J Med. 2006;354(25):2667-2676.

155. Günther J, Kill A, Becker MO, et al. Angiotensin receptor type 1 and endothelin receptor type $\mathrm{A}$ on immune cells mediate migration and the expression of IL- 8 and CCL18 when stimulated by autoantibodies from systemic sclerosis patients. Arthritis Res Ther. 2014; 16(2):R65.

156. Carvalho D, Savage CO, Black CM, Pearson JD. IgG antiendothelial cell autoantibodies from scleroderma patients induce leukocyte adhesion to human vascular endothelial cells in vitro. Induction of adhesion molecule expression and involvement of endothelium-derived cytokines. J Clin Invest. 1996;97(1):111-119.

157. Ahmed SS, Tan FK, Arnett FC, Jin L, Geng YJ. Induction of apoptosis and fibrillin 1 expression in human dermal endothelial cells by scleroderma sera containing anti-endothelial cell antibodies. Arthritis Rheum. 2006;54(7):2250-2262.

158. Sgonc R, Gruschwitz MS, Boeck G, Sepp N, Gruber J, Wick G. Endothelial cell apoptosis in systemic sclerosis is induced by antibodydependent cell-mediated cytotoxicity via CD95. Arthritis Rheum. 2000;43(11):2550-2562.

159. Chizzolini C, Raschi E, Rezzonico R, et al. Autoantibodies to fibroblasts induce a proadhesive and proinflammatory fibroblast phenotype in patients with systemic sclerosis. Arthritis Rheum. 2002;46(6):1602-1613.

160. Ronda N, Raschi E, Testoni C, et al. Anti-fibroblast antibodies in systemic sclerosis. Isr Med Assoc J. 2002;4(11 Suppl):858-864.

161. Tan FK, Arnett FC, Antohi S, et al. Autoantibodies to the extracellular matrix microfibrillar protein, fibrillin-1, in patients with scleroderma and other connective tissue diseases. J Immunol. 1999;163(2):1066-1072.

162. Sato S, Hayakawa I, Hasegawa M, Fujimoto M, Takehara K. Function blocking autoantibodies against matrix metalloproteinase-1 in patients with systemic sclerosis. J Invest Dermatol. 2003;120(4): 542-547.

163. Nishijima C, Hayakawa I, Matsushita T, et al. Autoantibody against matrix metalloproteinase- 3 in patients with systemic sclerosis. Clin Exp Immunol. 2004;138(2):357-363.

164. Nagaraja V, Denton CP, Khanna D. Old medications and new targeted therapies in systemic sclerosis. Rheumatology. 2015; 54(11):1944-1953.

165. Amjadi S, Maranian P, Furst DE, et al. Course of the modified Rodnan skin thickness score in systemic sclerosis clinical trials: analysis of three large multicenter, double-blind, randomized controlled trials. Arthritis Rheum. 2009;60(8):2490-2498.

166. Pope JE, Bellamy N, Seibold JR, et al. A randomized, controlled trial of methotrexate versus placebo in early diffuse scleroderma. Arthritis Rheum. 2001;44(6):1351-1358.

167. Tashkin DP, Elashoff R, Clements PJ, et al. Cyclophosphamide versus placebo in scleroderma lung disease. $N$ Engl $J$ Med. 2006;354(25):2655-2666.

168. Mendoza FA, Nagle SJ, Lee JB, Jimenez SA. A prospective observational study of mycophenolate mofetil treatment in progressive diffuse cutaneous systemic sclerosis of recent onset. $J$ Rheumatol. 2012;39(6):1241-1247.

169. Le EN, Wigley FM, Shah AA, Boin F, Hummers LK. Long-term experience of mycophenolate mofetil for treatment of diffuse cutaneous systemic sclerosis. Ann Rheum Dis. 2011;70(6):1104-1107.

170. Tashkin DP, Elashoff R, Clements PJ, et al. Effects of 1-year treatment with cyclophosphamide on outcomes at 2 years in scleroderma lung disease. Am J Respir Crit Care Med. 2007;176(10):1026-1034. 
171. Hoyles RK, Ellis RW, Wellsbury J, et al. A multicenter, prospective, randomized, double-blind, placebo-controlled trial of corticosteroids and intravenous cyclophosphamide followed by oral azathioprine for the treatment of pulmonary fibrosis in scleroderma. Arthritis Rheum. 2006;54(12):3962-3970.

172. Becker MO, Schohe A, Weinert K, et al. Responders to cyclophosphamide: results of a single-centre analysis among systemic sclerosis patients. Ann Rheum Dis. 2012;71(12):2061-2062.

173. Espinosa G, Simeon CP, Plasin MA, et al. Efficacy of cyclophospamide in the treatment of interstitial lung disease associated with systemic sclerosis. Arch Bronconeumol. 2011;47(5):239-245.

174. Domiciano DS, Bonfá E, Borges CT, et al. A long-term prospective randomized controlled study of non-specific interstitial pneumonia (NSIP) treatment in scleroderma. Clin Rheumatol. 2011;30(2): 223-229.

175. Abhishek A, Yazdani R, Pearce F, et al. Outcome of systemic sclerosis associated interstitial lung disease treated with intravenous cyclophosphamide. Clin Rheumatol. 2011;30(8):1099-1104.

176. Poormoghim H, Moradi Lakeh M, Mohammadipour M, Sodagari F, Toofaninjed N. Cyclophosphamide for scleroderma lung disease: a systematic review and meta-analysis. Rheumatol Int. 2012;32(8): 2431-2444.

177. Poormoghim H, Rezaei N, Sheidaie Z, et al. Systemic sclerosis: comparison of efficacy of oral cyclophosphamide and azathioprine on skin score and pulmonary involvement-a retrospective study. Rheumatol Int. 2014;34(12):1691-1699.

178. Schachna L, Medsger TA Jr, Dauber JH, et al. Lung transplantation in scleroderma compared with idiopathic pulmonary fibrosis and idiopathic pulmonary arterial hypertension. Arthritis Rheum. 2006;54(12):3954-3961.

179. Prey S, Ezzedine K, Doussau A, et al. Imatinib mesylate in scleroderma-associated diffuse skin fibrosis: a phase II multicentre randomized double-blinded controlled trial. $\mathrm{Br} J$ Dermatol. 2012;167(5):1138-1144.

180. Pope J, McBain D, Petrlich L, et al. Imatinib in active diffuse cutaneous systemic sclerosis: results of a six-month, randomized, double-blind, placebo-controlled, proof-of-concept pilot study at a single center. Arthritis Rheum. 2011;63(11):3547-3551.

181. Khanna D, Saggar R, Mayes MD, et al. A one-year, phase I/IIa, openlabel pilot trial of imatinib mesylate in the treatment of systemic sclerosis-associated active interstitial lung disease. Arthritis Rheum. 2011;63(11):3540-3546.

182. Fraticelli P, Gabrielli B, Pomponio G, et al. Low-dose oral imatinib in the treatment of systemic sclerosis interstitial lung disease unresponsive to cyclophosphamide: a phase II pilot study. Arthritis Res Ther. 2014;16(4):R144.

183. Bosello S, De Santis M, Lama G, et al. B cell depletion in diffuse progressive systemic sclerosis: safety, skin score modification and IL-6 modulation in an up to thirty-six months follow-up open-label trial. Arthritis Res Ther. 2010;12(2):R54.

184. Jordan S, Distler JH, Maurer B, et al. Effects and safety of rituximab in systemic sclerosis: an analysis from the European Scleroderma Trial and Research (EUSTAR) group. Ann Rheum Dis. 2015;74(6): 1188-1194.

185. Manno R, Boin F. Immunotherapy of systemic sclerosis. Immunotherapy. 2010;2(6):863-878.

186. Takehara K, Ihn H, Sato S. A randomized, double-blind, placebocontrolled trial: intravenous immunoglobulin treatment in patients with diffuse cutaneous systemic sclerosis. Clin Exp Rheumatol. 2013; 31(2 Suppl 76):151-156.

187. Poelman CL, Hummers LK, Wigley FM, Anderson C, Boin F, Shah AA. Intravenous immunoglobulin may be an effective therapy for refractory, active diffuse cutaneous systemic sclerosis. J Rheumatol. 2015;42(2):236-242.
188. Burt RK, Shah SJ, Dill K, et al. Autologous non-myeloablative haemopoietic stem-cell transplantation compared with pulse cyclophosphamide once per month for systemic sclerosis (ASSIST): an open-label, randomised phase 2 trial. Lancet. 2011;378(9790): 498-506.

189. van Laar JM, Farge D, Sont JK, et al. Autologous hematopoietic stem cell transplantation vs intravenous pulse cyclophosphamide in diffuse cutaneous systemic sclerosis: a randomized clinical trial. JAMA. 2014;311(24):2490-2498.

190. Cras A, Farge D, Carmoi T, Lataillade JJ, Wang DD, Sun L. Update on mesenchymal stem cell-based therapy in lupus and scleroderma. Arthritis Res Ther. 2015;17:301.

191. Larghero J, Farge D, Braccini A, et al. Phenotypical and functional characteristics of in vitro expanded bone marrow mesenchymal stem cells from patients with systemic sclerosis. Ann Rheum Dis. 2008;67(4):443-449.

192. Bocelli-Tyndall C, Bracci L, Spagnoli G, et al. Bone marrow mesenchymal stromal cells (BM-MSCs) from healthy donors and auto-immune disease patients reduce the proliferation of autologousand allogeneic-stimulated lymphocytes in vitro. Rheumatology. 2007;46(3):403-408.

193. Le Blanc K, Tammik C, Rosendahl K, Zetterberg E, Ringdén O. HLA expression and immunologic properties of differentiated and undifferentiated mesenchymal stem cells. Exp Hematol. 2003;31(10):890-896.

194. Caplan AI, Dennis JE. Mesenchymal stem cells as trophic mediators. $J$ Cell Biochem. 2006;98(5):1076-1084.

195. Dazzi F, Horwood NJ. Potential of mesenchymal stem cell therapy. Curr Opin Oncol. 2007;19(6):650-655.

196. Di Nicola M, Carlo-Stella C, Magni M, et al. Human bone marrow stromal cells suppress T-lymphocyte proliferation induced by cellular or nonspecific mitogenic stimuli. Blood. 2002;99(10):3838-3843.

197. Jiang XX, Zhang Y, Liu B, et al. Human mesenchymal stem cells inhibit differentiation and function of monocyte-derived dendritic cells. Blood. 2005;105(10):4120-4126.

198. Nauta AJ, Kruisselbrink AB, Lurvink E, Willemze R, Fibbe WE. Mesenchymal stem cells inhibit generation and function of both CD34+-derived and monocyte-derived dendritic cells. J Immunol. 2006;177(4):2080-2087.

199. Ramasamy R, Fazekasova H, Lam EW, Soeiro I, Lombardi G, Dazzi F. Mesenchymal stem cells inhibit dendritic cell differentiation and function by preventing entry into the cell cycle. Transplantation. 2007;83(1):71-76.

200. Vanneaux V, Farge-Bancel D, Lecourt S, et al. Expression of transforming growth factor beta receptor II in mesenchymal stem cells from systemic sclerosis patients. BMJ Open. 2013;3(1):e001890.

201. Meisel R, Zibert A, Laryea M, Göbel U, Däubener W, Dilloo D. Human bone marrow stromal cells inhibit allogeneic T-cell responses by indoleamine 2,3-dioxygenase-mediated tryptophan degradation. Blood. 2004;103(12):4619-4621.

202. Cipriani P, Di Benedetto P, Liakouli V, et al. Mesenchymal stem cells (MSCs) from scleroderma patients (SSc) preserve their immunomodulatory properties although senescent and normally induce $\mathrm{T}$ regulatory cells (Tregs) with a functional phenotype: implications for cellular-based therapy. Clin Exp Immunol. 2013;173(2):195-206.

203. Christopeit M, Schendel M, Foll J, Muller LP, Keysser G, Behre G. Marked improvement of severe progressive systemic sclerosis after transplantation of mesenchymal stem cells from an allogeneic haploidentical-related donor mediated by ligation of CD137L. Leukemia. 2008;22(5):1062-1064.

204. Keyszer G, Christopeit M, Fick S, et al. Treatment of severe progressive systemic sclerosis with transplantation of mesenchymal stromal cells from allogeneic related donors: report of five cases. Arthritis Rheum. 2011;63(8):2540-2542. 
205. Milano A, Pendergrass SA, Sargent JL, et al. Molecular subsets in the gene expression signatures of scleroderma skin. PLoS One. 2008;3(7):e2696.

206. Pendergrass SA, Lemaire R, Francis IP, Mahoney JM, Lafyatis R, Whitfield ML. Intrinsic gene expression subsets of diffuse cutaneous systemic sclerosis are stable in serial skin biopsies. $J$ Invest Dermatol. 2012;132(5):1363-1373.
207. Johnson ME, Mahoney JM, Taroni J, et al. Experimentally-derived fibroblast gene signatures identify molecular pathways associated with distinct subsets of systemic sclerosis patients in three independent cohorts. PLoS One. 2015;10(1):e0114017.

208. Martyanov V, Whitfield ML. Molecular stratification and precision medicine in systemic sclerosis from genomic and proteomic data. Curr Opin Rheumatol. 2016;28(1):83-88.

\section{Publish your work in this journal}

ImmunoTargets and Therapy is an international, peer-reviewed open access journal focusing on the immunological basis of diseases, potential targets for immune based therapy and treatment protocols employed to improve patient management. Basic immunology and physiology of the immune system in health, and disease will be also covered. In addition, the journal will focus on the impact of manage-

Submit your manuscript here: http://www.dovepress.com/immunotargets-and-therapy-journal

\section{Dovepress}

ment programs and new therapeutic agents and protocols on patient perspectives such as quality of life, adherence and satisfaction. The manuscript management system is completely online and includes a very quick and fair peer-review system, which is all easy to use. Visit http://www.dovepress.com/testimonials.php to read real quotes from published authors. 